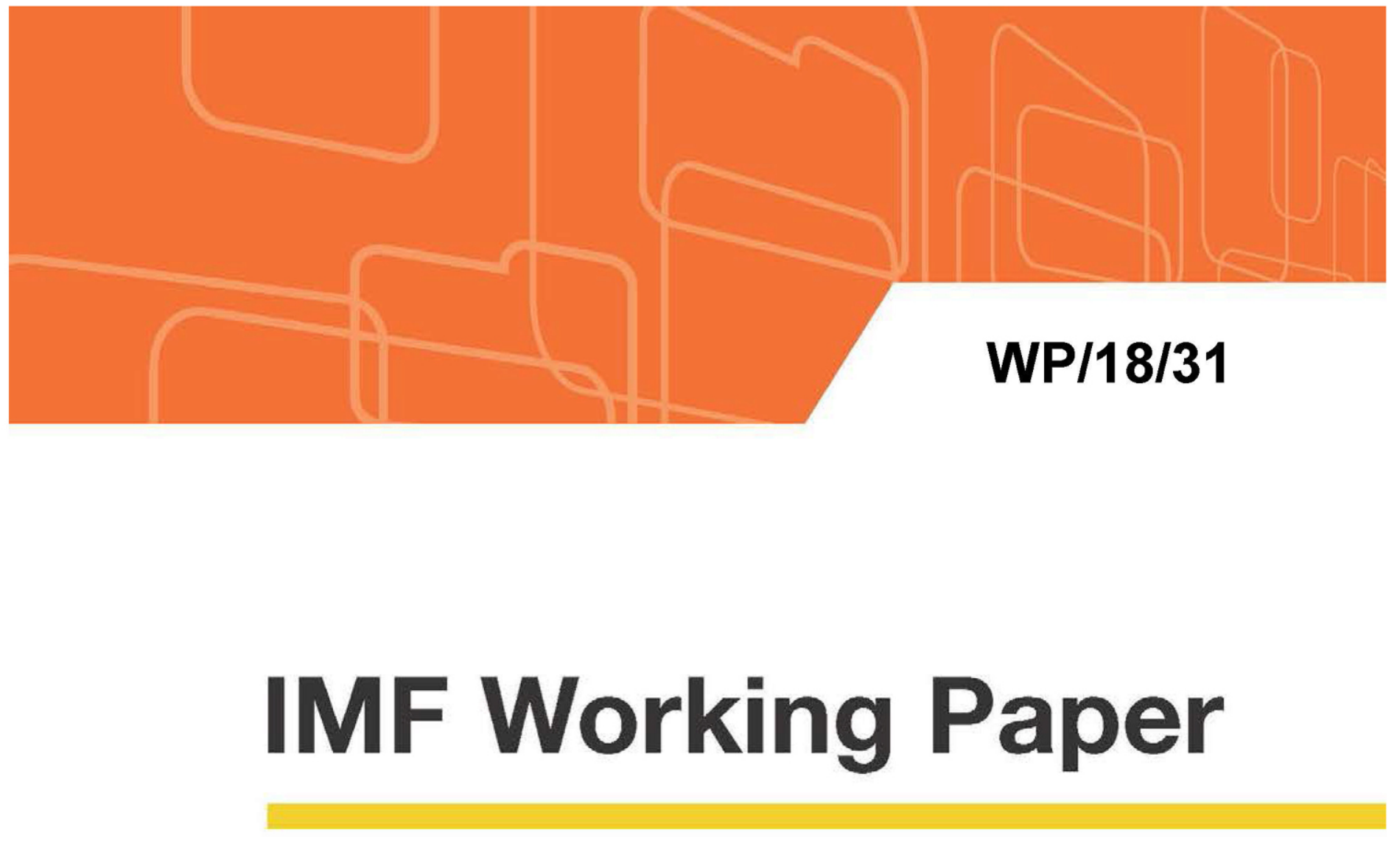

\title{
Central Bank Reserve Management and International Financial Stability-Some Post-Crisis Reflections
}

\author{
by Bradley A. Jones
}

IMF Working Papers describe research in progress by the author(s) and are published to elicit comments and to encourage debate. The views expressed in IMF Working Papers are those of the author(s) and do not necessarily represent the views of the IMF, its Executive Board, or IMF management. 


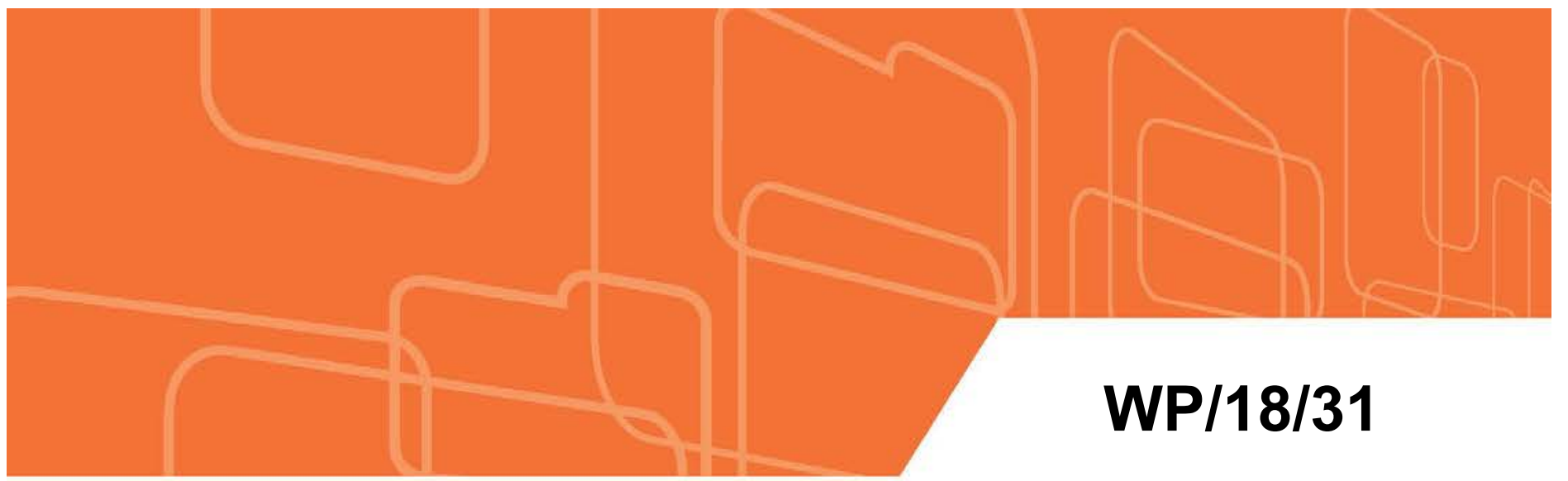

\section{IMF Working Paper}

\section{Central Bank Reserve Management and International Financial Stability-Some Post-Crisis Reflections}

by Bradley A. Jones

IMF Working Papers describe research in progress by the author(s) and are published to elicit comments and to encourage debate. The views expressed in IMF Working Papers are those of the author(s) and do not necessarily represent the views of the IMF, its Executive Board, or IMF management.

$$
\text { I N T E R N A T I O N A L M O N E T A R Y F U N D }
$$




\title{
IMF Working Paper
}

\author{
Monetary and Capital Markets Department
}

\author{
Central Bank Reserve Management and International Financial Stability \\ -Some Post-Crisis Reflections ${ }^{1}$ \\ Prepared by Bradley A. Jones \\ Authorized for distribution by Daniel Hardy
}

February 2018

\begin{abstract}
IMF Working Papers describe research in progress by the author(s) and are published to elicit comments and to encourage debate. The views expressed in IMF Working Papers are those of the author(s) and do not necessarily represent the views of the IMF, its Executive Board, or IMF management.
\end{abstract}

\begin{abstract}
Motivated by the tension first revealed during the global financial crisis between the domestic and international financial stability obligations of central bank reserve managers, this paper offers some reflections along four main lines. First, the paper highlights how official reserve management has evolved to mirror important aspects of private institutional investor behavior over time, and addresses the policy relevance of this convergence. Second, evidence is documented of procyclical portfolio behavior by reserve managers during the crisis, which added to the stabilization burden shouldered by central banks in reserve currency-issuing countries. Third, in appraising the evolution of related vulnerabilities since the crisis, the paper finds grounds for both cautious optimism and lingering concern, the balance of which points to an uncertain future resolution. Fourth, some potential remedies are presented to help dampen the procyclical impulses of reserve managers in future periods of international financial turbulence.
\end{abstract}

JEL Classification Numbers: E44, E58, F31, F55, G01, G11, G15, G23.

Keywords: Central bank reserve management, financial stability, risk management.

Author's E-Mail Address: bjones@imf.org

\footnotetext{
${ }^{1}$ The author wishes to thank Abdullah Al Hassan, Myles Brennan, Max Castelli, Varapat Chensavasdijai, Kelly Eckhold, Pascal Farahmand, Daniel Hardy, Yinqiu Lux, Bob McCauley, Michael Papaioannou, Robert Patalano, Steve Phillips, Jukka Pihlman, Manmohan Singh, and Rudy Wytenburg for comments. Remaining errors are the author's alone.
} 


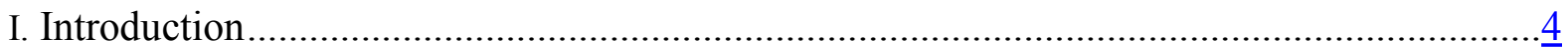

II. The Evolution of Reserve Management_—An Institutional View .................................

III. Procyclical Reserve Management in the Crisis ..........................................................

IV. Looking Ahead-The Balance of Vulnerabilities ….......................................... 15

V. Dampening Procyclicality_-What Can be Done? .................................................

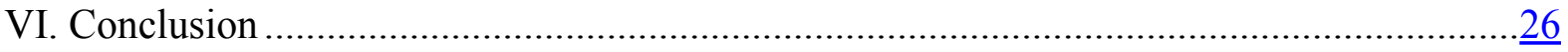

Tables

1. A Taxonomy of Constraints for Institutional Asset Owners ..........................................

Figures

1. Official World Foreign Exchange Reserve Holdings ...................................................

2. Central Bank Exposures to Foreign Commercial and Central Banks.................................. 11

3. Decline in Bank Deposits of Official Monetary Authorities ........................................... $\frac{11}{12}$

4. Foreign Official Net Purchases of U.S. Securities..........................................................12

5. Approved Asset Classes for Reserve Managers …..................................................... $\frac{13}{13}$

6. Trigger for Major Asset Allocation Changes by Reserve Managers in the Crisis...............13

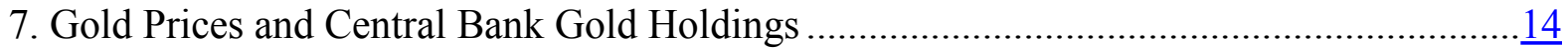

8. Reserve Manager Deposits ....................................................................................... $\frac{15}{17}$

9. Concentration of World FX Reserve Holdings............................................................... $\frac{17}{18}$

10. Foreign Official Ownership Share of Market Cap................................................... 18

11. Foreign Official Ownership Share of Sovereign Debt...............................................18

12. Foreign Official Ownership Share of Sovereign Debt: Procyclical Asset Classes.............18

13. Share of World FX Reserves: Non-Traditional Currencies ...........................................19

14. Foreign Official Duration Exposure in the U.S. ..................................................... $\frac{20}{20}$

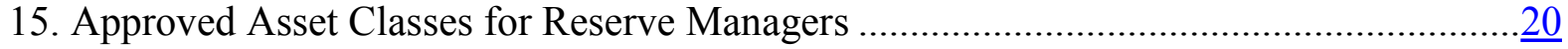

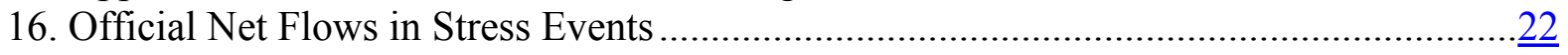






\section{INTRODUCTION}

For much of the period following the introduction of the classical gold standard in the midlate nineteenth century, the portfolio behavior of central bank reserve managers was a prosaic affair. Reserves were typically of modest size and passively managed in a small set of conservative investments (mostly non-yielding bullion, and later, short-term bills), reflecting the risk averse proclivities of liability-driven central banks acting as fiduciary trustees of public assets. As Eichengreen and Flandreau (2016) point out, "Compared to today, the issues then surrounding the holding of foreign assets by banks of issue, as central banks were known, were so simple as to appear almost rudimentary." In the interwar years, large losses experienced by the few central banks (notably those of France, Belgium and the Netherlands) willing to search for yield underscored the perils of investment adventurism. The principal occupation of most reserve managers was therefore operational cost control and discharging administrative duties - not generating active investment returns in security markets (Nugée, 2015). Prior to the breakdown of the Bretton Woods fixed exchange rate system in the 1970s, in many central banks investment returns were not even reported, and as a result, the behavior of reserve managers rarely featured in analysis or discussion either within policy agencies or in a wider public setting (Hong Kong Monetary Authority, 1997). Consequently, their actions typically attracted only sporadic attention from private market participants in countries in which reserve assets were invested.

In the post-Bretton Woods era, it was the years preceding the global financial crisis of 2008 that marked a fundamental shift in the broader operating environment for reserve managers. ${ }^{2}$ This reflected unprecedented growth in the size (and increasing concentration) of reserve assets (in turn largely a response to the policy objectives of large emerging market countries), and the more expansive risk tolerance occasioned by such growth. As this paper seeks to illuminate, it was in this context that events during the global financial crisis first revealed a tension between the domestic and international financial stability obligations of reserve managers. More concretely, this paper argues that a key lesson from the global financial crisis is as follows: what might appear to be rational behavior for the individual reserve manager in a panic - cutting losses on security holdings, pulling unsecured bank funding and demanding liquidity to bolster the domestic central bank balance sheet - can inadvertently amplify negative externalities for the wider international financial system. Under certain conditions - where international reserve assets are large and concentrated, and the portfolio actions of reserve managers become synchronized with one another and other private sector investors in moving procyclically to correct earlier misjudgments of liquidity and investment risk - the burden of stabilization can increase on other central banks, principally those of countries with reserve currency-issuing responsibilities.

Curiously, however, the policy implications associated with this issue, and what might be done about it, have received relatively little attention - in contrast to the extensive literature on reserve adequacy (focused on the determination of the appropriate level of reserves, rather

\footnotetext{
${ }^{2}$ For discussion of the evolution in liability-driven reserve management practices back to the mid nineteenth century, with emphasis on shifts in the gold/foreign exchange ratio, see Eichengreen and Flandreau (2016).
} 
than how they are invested) which has continued to swell virtually unabated since the crisis. ${ }^{3}$ The banking-centric study of Pihlman and van der Hoorn (2010), and the securities market treatment in McCauley and Rigaudy (2011) are therefore valuable contributions, and usefully supplemented by the survey of Morahan and Mulder (2013), albeit the event-study orientation of these previous works leaves them confined mainly to documenting aspects of reserve manager behavior in the crisis. Events during the crisis also prompted the revised Guidelines for Foreign Exchange Reserve Management (IMF, 2013) to recognize the issue and make reference to reserve managers' obligations in giving consideration to the risk of market disruptions directly or indirectly (through signaling effects) induced by their actions, ${ }^{4}$ but, as high-level Guidelines, they understandably stop short of weighing conjunctural vulnerabilities or setting out prescriptive remedies.

More broadly, while dampening procyclicality in the banking sector has attracted the attention of policy makers for the better part of a few centuries, the issue as it relates to large institutional investors, and asset owners in particular, has been a relative greenfield area. But with institutional asset owners - central banks, sovereign wealth funds (SWFs), pension funds, insurers, endowments, and foundations - now administering a larger pool of capital than banks (a gap that is widening), attention is now beginning to shift. ${ }^{5}$ In part this reflects growing awareness that if institutional arrangements and incentives result in the willingness to bear risk diminishing in stress periods and increasing in upturns, capital can be misallocated, and moreover, movements in risk premiums can be magnified to an extent that sets off economically harmful feedback loops.

Against this backdrop, the analysis that follows attempts to advance the related literature along four main lines. First, the paper highlights how official reserve management has evolved to mirror important aspects of private institutional investor behavior over time, and notes the policy relevance of this gradual convergence (Section II). Second, evidence is

\footnotetext{
${ }^{3}$ See for instance, IMF (2015, 2016), and Obstfeld et al. (2009).

${ }^{4}$ Guideline 59 in IMF (2013) states: "In choosing strategic asset allocation and investment options, attention should be paid to the risk of possible disruptive impacts on credit and financial markets and of excessive liquidation or acquisition costs. The risk of an impact on markets depends on the size of the operations relative to the specific market and on the speed of the portfolio adjustment. It also depends on external market conditions. For instance, in times of rapidly rising or falling prices of particular asset classes, operations in those assets by official reserve holders, in the same direction as the markets are moving, may fuel market trends and imply high liquidation or acquisition costs. Particular attention should also be paid to possible signaling effects, since actions by official reserve holders are followed closely by market participants."

${ }^{5}$ See for instance, Bank of England (2014), OECD (2014), IMF (2014) and Jones (2016, 2017). Note that most of the related stability analysis on institutional investors has been concentrated on asset managers, rather than asset owners (for analysis of 'structural vulnerabilities' posed by asset management activities, see most recently, Financial Stability Board, 2017). However, sometimes lost in the discussion is that most asset managers are highly constrained vis-à-vis asset owners, and they are often viewed as responsible for actions that are essentially just the passing through of asset owner decisions. Asset owners are principally responsible for the large strategic shifts of capital across asset classes and geographies. To the extent asset managers amplify procyclicality in their tactical decisions, it can often be a response to the performance appraisal terms imposed by asset owners (Jones, 2016).
} 
documented of procyclical portfolio behavior by reserve managers during the crisis, which, in adding to the stabilization burden of central banks in reserve issuing countries, gave rise to a tension between their domestic and international financial stability obligations (Section III). Third, in appraising the evolution of related vulnerabilities since the crisis, the paper finds grounds for both optimism and lingering concern, the balance of which points to an uncertain future resolution (Section IV). Fourth, some remedies are proposed to help ensure reserve managers are better prepared to navigate future periods of international financial turmoil (Section V). The paper concludes with suggestions for future research (Section VI).

\section{The Evolution of Reserve Management -An Institutional VieW}

Central bank reserve managers have long constituted a special breed of institutional asset owner. While all asset owners (in both the public and private sphere) have liability-hedging responsibilities and face constraints of various forms, in no other context have these tended to be more pronounced than for reserve managers (Table 1). ${ }^{6}$ In a historical sense at least, most notable has been the subordination of return generation to a broader set of policy objectives, reflecting that the narrow activity of reserve management is nested in the broader, non-profit maximizing objectives of the central bank as a whole. ${ }^{7}$ Understanding the types of investment and liquidity risks the reserve manager will be willing and able to bear therefore first requires understanding the institutional and economic rationale for holding reserves, and the circumstances in which they might be called upon. ${ }^{8}$

When not accumulating as a passive byproduct of regular intervention, ${ }^{9}$ the rationale for holding reserves can be broadly categorized along precautionary insurance ('war chest') and standard operational lines. Precautionary reserves are held to defend the exchange rate against destabilizing capital outflows; to grant emergency foreign currency liquidity assistance to banks; and to lean against disorderly market conditions and/or valuation overshooting. The operational functions served by reserves include facilitating regular international debt and import-related payments made on behalf of the government, serving as collateral to relax external borrowing constraints, and assisting with monetary policy related liquidity operations. Policy credibility, the exchange rate regime (fixed, floating, currency

\footnotetext{
${ }^{6}$ Stabilization-based SWFs bear the closest resemblance to central bank reserve managers in this regard, albeit their purpose is somewhat narrower. These funds aim (almost exclusively) to dampen the impact of external shocks on the fiscal budget, where the government collects a sizeable proportion of tax revenues from a single, highly volatile source (i.e., commodity exports).

${ }^{7}$ In pursuit of its policy aims, a central bank will occasionally be compelled to take actions that are detrimental to its own pecuniary interests. For instance, raising interest rates can increase the cost of sterilizing unhedged foreign exchange reserves and reduce the value of domestic securities holdings.

${ }^{8}$ Though the following discussion is not an exhaustive list of factors impacting the risk tolerance and asset allocation of the reserve manager, others, such as the choice of numeraire currency, accounting treatment of profits and capital, and reputational considerations, are more tangential to the focus of this paper and addressed later in Section V.

${ }^{9}$ This refers to the source of reserves, while the rest of the paragraph speaks to the motives for holding them.
} 
union), the degree of dollarization, range of domestic instruments available for monetary operations, and other (shock absorbing) characteristics of the economic and financial system all feature in the determination of the appropriate level of international reserves. The implication is that in an institutional and economic context whereby reserve management is strictly liability-driven, liquidity and safety are paramount.

Table 1.

A Taxonomy of Constraints for Institutional Asset Owners

\begin{tabular}{|c|c|c|c|c|c|c|c|}
\hline $\begin{array}{l}\text { Asset Owner } \\
\text { Type }\end{array}$ & $\begin{array}{l}\text { Financial } \\
\text { Stability } \\
\text { Objectives }\end{array}$ & $\begin{array}{l}\text { Nature of } \\
\text { Liabilities }\end{array}$ & $\begin{array}{l}\text { Short-term } \\
\text { Liquidity } \\
\text { Needs }\end{array}$ & $\begin{array}{l}\text { Reputational } \\
\text { Concerns }\end{array}$ & $\begin{array}{l}\text { Regulatory } \\
\text { Constraints }\end{array}$ & $\begin{array}{c}\text { Peer } \\
\text { Bench- } \\
\text { marking }\end{array}$ & $\begin{array}{c}\text { ESG } \\
\text { Concerns }\end{array}$ \\
\hline $\begin{array}{l}\text { Central Bank } \\
\text { Reserve } \\
\text { Managers }\end{array}$ & $\begin{array}{c}\text { High } \\
\text { Importance }\end{array}$ & $\begin{array}{c}\text { Explicit/ } \\
\text { Contingent }\end{array}$ & High & High & n.a. & Low & n.a. \\
\hline $\begin{array}{l}\text { Stabilization- } \\
\text { based SWFs }\end{array}$ & $\begin{array}{l}\text { Medium/ } \\
\text { High } \\
\text { Importance }\end{array}$ & $\begin{array}{c}\text { Explicit/ } \\
\text { Contingent }\end{array}$ & High & High & n.a. & Low & n.a. \\
\hline $\begin{array}{l}\text { Savings-based } \\
\text { SWFs }\end{array}$ & $\begin{array}{l}\text { Medium/ } \\
\text { Low } \\
\text { Importance }\end{array}$ & Implicit & Low & High & n.a. & $\begin{array}{l}\text { Medium/ } \\
\text { High }\end{array}$ & Medium \\
\hline $\begin{array}{l}\text { Defined Benefit } \\
\text { Pension Funds }\end{array}$ & n.a. & Explicit & $\begin{array}{l}\text { Medium/ } \\
\text { Low }\end{array}$ & Medium & High & Medium & Medium \\
\hline $\begin{array}{l}\text { Defined } \\
\text { Contribution } \\
\text { Pension Funds }\end{array}$ & n.a. & Implicit & Low & $\begin{array}{l}\text { Medium/ } \\
\text { Low }\end{array}$ & Medium & $\begin{array}{l}\text { Medium/ } \\
\text { High }\end{array}$ & $\begin{array}{l}\text { Medium/ } \\
\text { High }\end{array}$ \\
\hline $\begin{array}{l}\text { Insurance } \\
\text { Companies }\end{array}$ & n.a. & $\begin{array}{c}\text { Explicit/ } \\
\text { Contingent }\end{array}$ & $\begin{array}{l}\text { Medium/ } \\
\text { Low }\end{array}$ & $\begin{array}{l}\text { Medium/ } \\
\text { Low }\end{array}$ & High & Medium & $\begin{array}{l}\text { Medium/ } \\
\text { Low }\end{array}$ \\
\hline $\begin{array}{l}\text { Endowments } \\
\text { \& Foundations }\end{array}$ & n.a. & Implicit & Low & $\begin{array}{l}\text { Medium/ } \\
\text { High }\end{array}$ & Low & High & $\begin{array}{l}\text { Medium/ } \\
\text { High }\end{array}$ \\
\hline
\end{tabular}

However, where reserve levels exceed those deemed necessary purely for liability-hedging purposes - possibly the result of intervention aimed at resisting upward pressure on the local exchange rate ${ }^{10}$ _opportunity costs tend to assume a more prominent place in the central bank objective function, leading to an increase in risk tolerance. The question of how to deploy these 'surplus reserves' (or 'excess balances') most appropriately therefore becomes highly relevant. Indeed, in stark contrast to the 1960s, when the dominant concern in international policy circles was the shortage of reserve assets (Aliber, 2011), the issue of deploying surplus reserves has become increasingly pertinent for a number of countries,

\footnotetext{
${ }^{10}$ Unless there is outstanding foreign currency debt that can be retired, it is generally difficult to reduce reserve levels without risking unwinding the original (desired) effect on the exchange rate. This owes to a change in gross reserves entailing a change in net reserves, with an impact equivalent to foreign exchange intervention.
} 
particularly in emerging markets (EM) which now account for around two-thirds of the world total. ${ }^{11}$

Since the East Asian and Russian crises of 1998, world reserves have expanded by \$US9.4 trillion, a six-fold increase (Figure 1). Relative to world trade, they have more than doubled over the same period, and tripled as a share of world GDP. This rate of asset growth has also far exceeded that observed for other large institutional asset owners, including global insurers and pension funds. And after a brief hiatus from 2014-16, official reserve growth recommenced in 2017.

\section{Figure 1.}

\section{Official World Foreign Exchange Reserve Holdings}

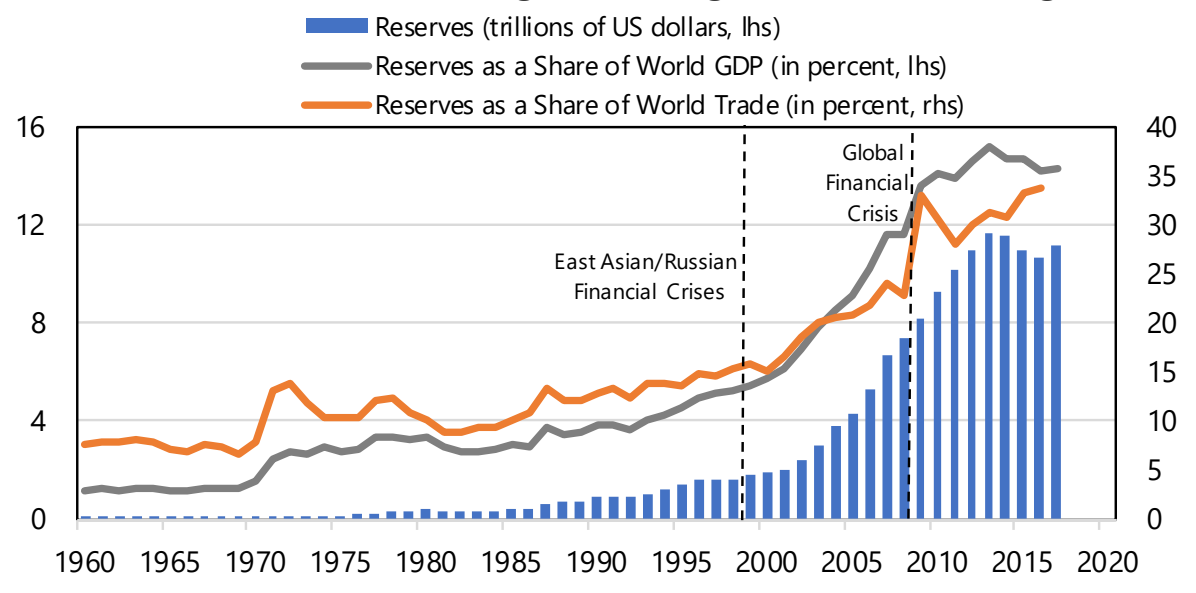

Sources: IMF, World Bank

\footnotetext{
${ }^{11}$ The merits of large scale reserve accumulation, most notably in East Asia, and the 'uphill' capital flows occasioned by it, have been the subject of intense policy debate. The literature on opportunity or indirect costs associated with reserve accumulation tends to divide along two lines: partial and general equilibrium analysis. In a (narrow) partial equilibrium sense, the net return on reserves is often approximated by the return on the portfolio (comprising foreign income and exchange rate changes) minus the cost of its financing as reflected in sterilization operations. For instance, Rodrik (2006) estimates the income loss due to 'excessive' reserve accumulation in EM countries to be close to 1 percent of GDP. However, general equilibrium analysis seeks to examine the broader question of how different the path of the macroeconomy would have been across different reserve levels. As noted in Borio et al. (2008b), the answer depends critically on views about how the economy works, including views on the effectiveness of foreign exchange intervention. As an example, the more expansive treatment of direct and indirect costs and benefits of reserve accumulation developed in the influential 'Revived Bretton Woods System' concept of Dooley, Folkerts Landau and Garber (2003, 2008, 2014) points to many EM countries (notably China) having been net beneficiaries over the period in which reserve growth far exceeded levels considered necessary for reserve adequacy purposes, reflecting the growth and employment benefits associated with heavy intervention. It is beyond the scope of this paper to weigh in on this discussion, other than to point out that one of the few areas of general agreement has been the emphasis on international reserves (reflecting the product of accumulated current account surpluses and sustained FX intervention) in serving as collateral for economies pursuing an export-led growth strategy with external borrowing constraints (resulting in part from perceptions of heightened political/economic risk).
} 
An important consequence of the sustained growth in official reserves has been not only to shift the balance of policy objectives more in the direction of return-generation (beyond the traditional mantra of 'safety and liquidity'), but also the convergence of reserve management investment practices with those of institutional investors in the private sector. This was a trend first observed in the years prior to the global financial crisis (Bernadell et al., 2004; Borio et al., 2008b; Pringle and Carver, 2008), and has broadly continued since. As detailed in the remainder of the paper, this development has found expression in various forms, not limited to: growing allocations to higher yielding and more complex asset classes whose returns are more procyclical than traditional reserve assets; more prevalent use of derivatives in tactical overlay strategies, and tactical trading strategies more generally; ${ }^{12}$ use of securities lending programs to enhance returns on high quality but low yielding securities; more reliance on specialist external asset managers to gain access to asset classes where in-house expertise is lacking; ${ }^{13}$ increased tranching of reserves into distinct short term liquidity-based and longer-term investment-oriented portfolios with separate guidelines; ${ }^{14}$ and rising interest in total return (benchmark agnostic) investment strategies as a response to the low interest rate environment. ${ }^{15}$

\section{Procyclical Reserve Management in the Crisis}

While the manner in which reserve assets can support external stability at the individual country level is relatively uncontroversial, it is less clear cut as to whether reserve management practices in aggregate are conducive to international financial stability. ${ }^{16}$ As Borio et al. (2008b) warned in the spring of 2008:

\section{"A more return-oriented strategy (by reserve managers) could potentially heighten the tension between individually profitable behaviour and shared responsibilities of public sector authorities for public goods, such as well functioning markets and}

\footnotetext{
${ }^{12}$ Surveys suggest the extent to which derivatives are used continues to vary widely across central banks-some now use close to the full range of currency and interest rate derivatives (mostly forwards and currency swaps, and less commonly, futures and interest rate swaps), while a non-trivial number employ a limited range or exclude them altogether (see for instance, Borio et al., 2008b, and Morahan and Mulder, 2013).

${ }^{13}$ Borio et al. (2008b) report survey results indicating that around two in every three central banks now employ external managers, though typically spanning only a small fraction (less than five percent) of reserves.

${ }^{14}$ Survey results indicate that between two thirds and four in five central banks now tranche reserves along these lines (Borio et al., 2008; Morahan and Mulder, 2013). The growth in assets managed by SWFs over the past one to two decades is an extension of the trend toward increased tranching of reserves into distinct liquidity and investment portfolios at the broader sovereign level.

15 The survey results in Carver and Glass (2017) suggest one in five managers currently employ this approach, with wider interest in active management more generally.

${ }^{16}$ It could be argued that international financial stability issues associated with rapid reserve growth and reserve manager portfolio allocation decisions first surfaced much earlier - in the 1980s Latin American debt crisis, following the earlier wave of reserve recycling through U.S. money center banks. A quasi-related and hotly debated issue prior to the global financial crisis was the extent to which unprecedented reserve accumulation may have compressed risk premia in the U.S. Treasury and other related markets. See also Section IV.
} 
financial stability ... retrenchment at times of stress could itself induce further stress in the markets, as assets whose returns are plunging are sold or hedged. This potential conflict increases as central banks push the envelope of risky asset classes."

As subsequent events during the global financial crisis appeared to lay bare (detailed below), a tension did emerge, in that the vigorous countercyclical policy response of central banks in the world's major financial centers was made more difficult, at least at the margin, by the procyclical portfolio actions of foreign reserve managers invested in the same centers. Expressed another way, in attempting to meet their (unexpected) domestic obligations in the crisis, the synchronized actions of reserve managers appeared to amplify negative externalities for the wider international financial system.

First, reserve managers significantly cut exposure to foreign commercial banks in advanced economies at the same time such banks were forced to seek emergency liquidity assistance from host central banks. From Q2-2007 to Q4-2010, reserve manager deposits with foreign commercial banks more than halved, a decline of more than US $\$ 300$ billion (Figure 2). The retrenchment was broad-based, with around half of surveyed central banks pulling deposits (Morahan and Mulder, 2013), and 85 percent also reducing deposit terms to facilitate withdrawals at short notice (Pringle and Carver, 2009). Continental European banks, to which reserve managers had been attracted by relatively high rates on U.S. dollar deposits, were particularly hard hit by reserve manager deposit outflows (Figure 3), amplifying the run by U.S. money market funds (MMFs) who also withdrew hundreds of billions of dollars from European banks in a matter of weeks following the Lehman Brothers collapse (Baba et al., 2009; McGuire and von Peter, 2009). ${ }^{17}$ The resulting destabilization of the dollar funding base of non-U.S. banks necessitated intervention by the U.S. Federal Reserve in the form of emergency swap lines with partner central banks in the order of US\$600 billion. ${ }^{18}$ Though some of the withdrawn deposits were redirected to the Bank for International Settlements (BIS), the BIS itself reduced uncollateralized exposure to commercial banks, by around US\$140 billion in the year to Q1-2009 (Pilhman and van der Hoorn, 2010). Reverse repo exposures with U.S. commercial banks were initially more resilient than bank deposits, until they too were cut sharply by foreign official investors in the post-Lehman panic.

\footnotetext{
${ }^{17}$ Foreign central banks and U.S. MMFs were the two main sources of dollar funding for non-U.S. banks.

${ }^{18}$ For data on the swap lines, see the Board of Governors of the Federal Reserve System H.4.1 release. For related policy discussion, see Fleming and Klagge (2010).
} 
Figure 2.

\section{Central Bank Exposures}

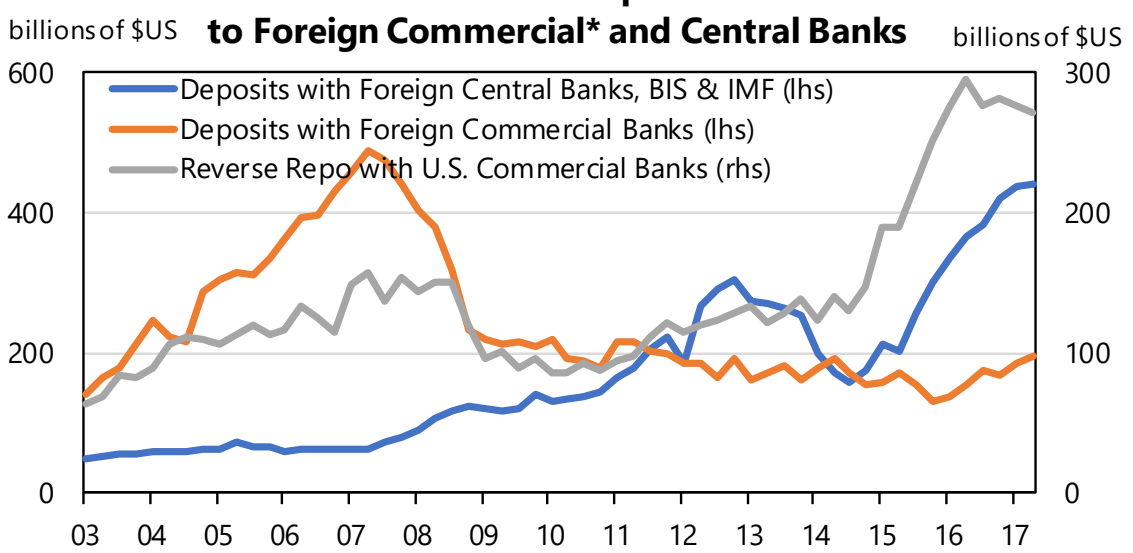

Source:IMF, U.S. Treasury Department

* Figu res for commercial bank deposits pertain to global banks; repo figures are for U.S. banks only

Figure 3.

Decline in Bank Deposits of Official Monetary Authorities (2007-2010 peak-to-trough decline, by bank nationality)

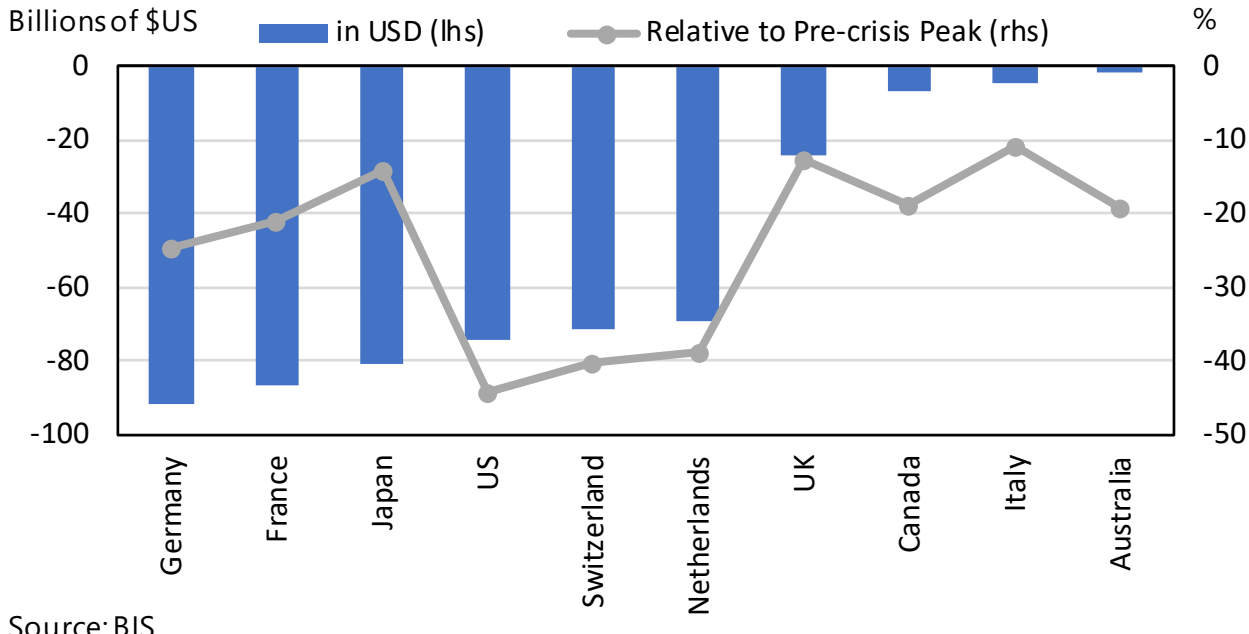

Source: BIS

A second illustration of procyclical behavior in the crisis could be seen in the heavy net sales by official sector investors of U.S. government agency debt and other short-dated spread product, with refuge sought, on an unprecedented scale, in U.S. Treasury bills (Figure 4). Having intensified their search for yield when spreads were narrow, reserve managers liquidated as spreads widened. Somewhat ironically, agency securities had been accumulated at least in part on the presumption of U.S. federal government support, but when that support 
materialized, official sector investment demand was notably absent. ${ }^{19}$ Combined holdings of agency debentures and bills, which had risen strongly prior to the crisis, were cut by US\$360 billion, or more than half, over the two years to June $2010,{ }^{20}$ while Treasury bill holdings, which had drifted lower in the years prior, surged from \$US177 billion in December 2006 to a peak of \$US607 billion in August 2009. This drove up the share of total outstanding Treasury bills held by foreign official investors from 19 to 29 percent. ${ }^{21}$

Figure 4.

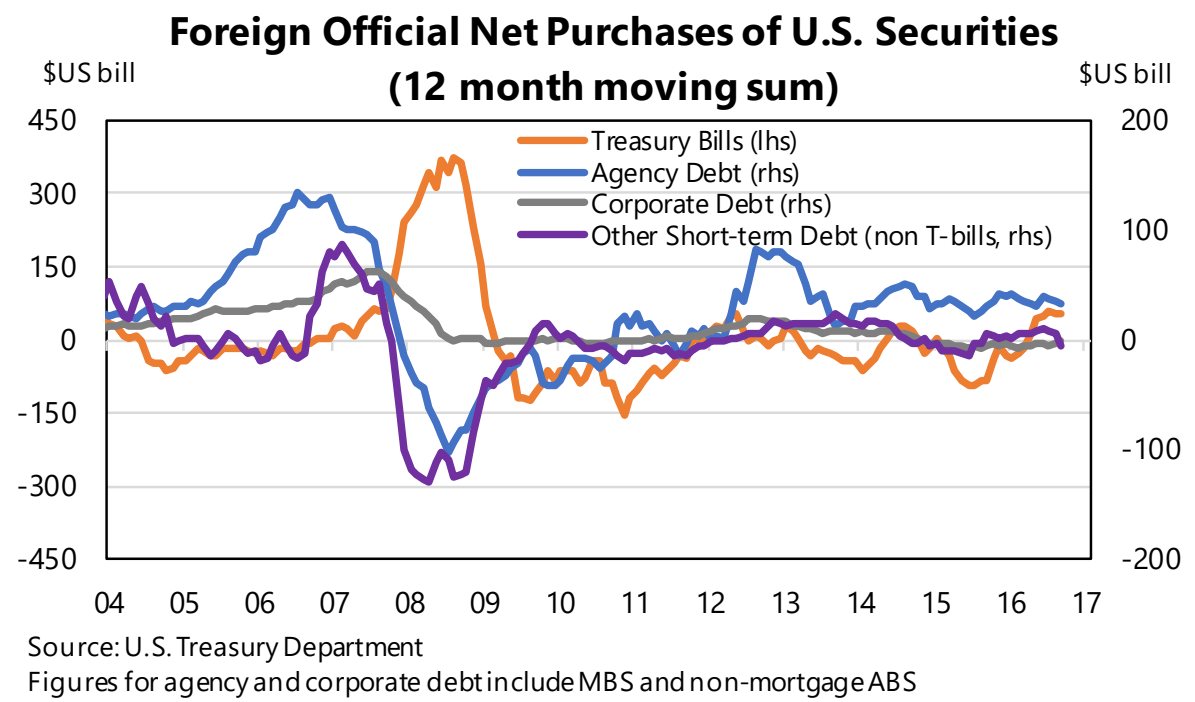

Third, reliance on credit ratings contributed to forced sales of downgraded securities, or resulted in the suspension or overhaul of rebalancing programs that otherwise would have provided countercyclical support for assets most under strain. For instance, the percentage of central banks for whom bank debt, mortgage and asset backed securities were deemed investable asset classes fell by around half relative to 2007 levels (Figure 5), and around one third of surveyed central banks cut exposure to government bonds that were downgraded (Morahan and Mulder, 2013). Rating downgrades, more than any other factor, prompted key changes to the asset allocation of reserve managers (Figure 6).

\footnotetext{
${ }^{19}$ Official holdings of agency mortgage backed securities held up much better than agency bills and debentures. It is an open question as to whether purchases by the U.S. Federal Reserve of agency debentures were at least partly motivated by knowledge that reserve managers were selling.

${ }^{20}$ Over the same period, equivalent foreign private investor holdings reduced by just $\$ 69$ billion to $\$ 401$ billion, suggesting a stronger procyclical impulse among official reserve managers in agency securities. In corporate securities however, foreign private investors reduced exposure more aggressively than reserve managers, though the latter's initial exposure to corporates was relatively modest in any case.

${ }^{21}$ When the U.S. Treasury accommodated the Federal Reserve's decision to sterilize dollars swapped with European central banks, it overfunded its cash flow needs by selling extra Treasury bills and depositing the proceeds in the Federal Reserve Bank of New York. As noted in McCauley and Rigaudy (2011), this meant there were more bills available into which foreign central banks and money market funds could flee.
} 
Figure 5.



Source: UBS Reserve Manager Survey

Figure 6.

Trigger for Major Asset Allocation Changes by Reserve Managers in the Global Financial Crisis

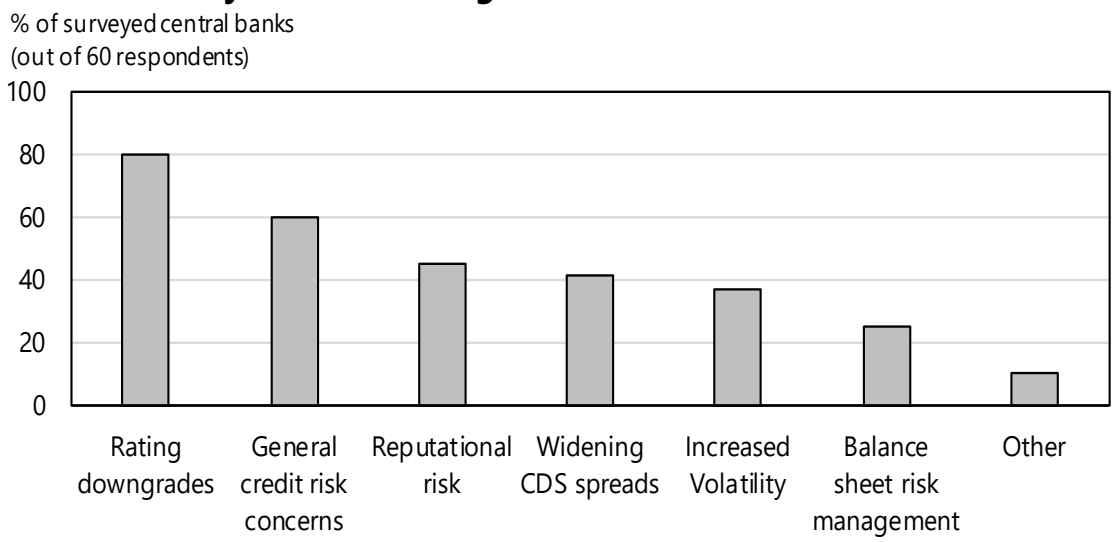

Source: Morahan and Mulder (2013)

Fourth, a number of central banks halted externally managed securities lending programs, thus inadvertently contributing to the run on shadow banking. In the years preceding the crisis, securities lending programs became a popular way for reserve managers to increase the return on high quality, low yielding securities in scarce supply. But not all reserve managers exercised the same oversight of reinvested cash collateral as with the direct management of their regular cash holdings. Some unexpectedly found that indemnity provisions covered only the failure of a counterparty to return lent securities, not losses incurred on reinvested cash. Additionally, because eligibility restrictions were often stipulated in terms of generic credit ratings, and structured product yields exceeded those on plain vanilla securities, cash raised through securities lending was often deployed in shadow 
banking vehicles unbeknown to the reserve manager. ${ }^{22}$ Problems with bank and broker-dealer sponsored structured credit funds, and reports that large custodians were gating the vehicles in which the cash collateral of reserve managers had been placed, sparked a wholesale retreat. Reserve manager securities lending programs reportedly fell from $\$ 340$ billion in August 2008 to $\$ 150$ billion in the first half of 2009 , with between one quarter and one half of lending programs shutdown entirely or materially de-risked (McCauley and Rigaudy, 2011; Morahan and Mulder, 2013).

Another manifestation of procyclical investment behavior, albeit the least disruptive for overall financial system functioning, saw reserve managers turn from net sellers to net buyers of gold over a period in which gold prices consistently made new highs during the quantitative easing policies of reserve-currency issuing central banks (Figure 7). The associated run-up in gold prices was accompanied by strong demand from EM central banks in particular, ${ }^{23}$ who accounted for $10-15$ percent of total incremental world gold demand. ${ }^{24}$ While the survey results in Carver (2013) reveal inflation protection to consistently rank as the main motivation for EM reserve managers in holding gold, it is notable that market-wide inflation expectations did not change in a meaningful way over this period. Morahan and Mulder (2013) instead infer from their reserve manager survey that increased EM demand could be driven more by "backward looking motives, i.e. extrapolating the trend in the price of gold rather than as a means to hedge against the tail risk of a surge in inflation." 25

Figure 7. Gold Prices and Central Bank Holdings

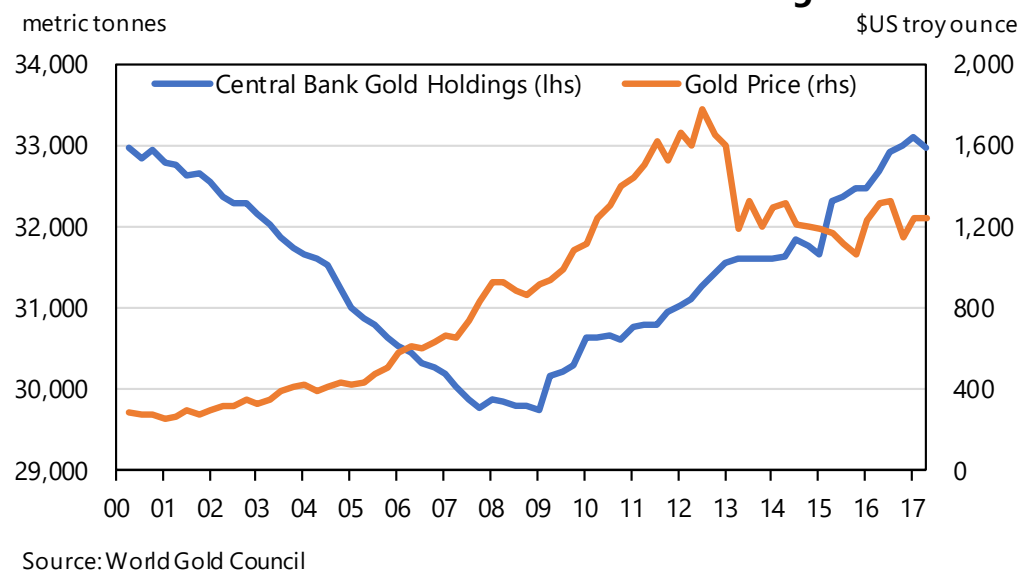

\footnotetext{
22 The incentive for agents to engage in maturity, liquidity and credit transformation was magnified where securities lenders operated a profit-sharing arrangement with the central bank.

${ }^{23}$ More precisely, around the time of the crisis, advanced economy central banks ceased net sales of gold, while EM central banks commenced net buying in greater magnitudes.

${ }^{24}$ Based on World Gold Council data.

${ }^{25}$ There may also have been an element of 'delayed catch-up' at play, in that the gold share of EM reserve assets had fallen markedly in the pre-crisis years (a period in which reserve growth surged).
} 
Finally, just over half of surveyed reserve managers conceded their response during the crisis highlighted a policy conflict between the core stabilization function of central banking in general, and their own investment actions during the panic (see Pringle and Carver, 2009; and Morahan and Mulder, 2013). This reflected not only the direct impact of their actions on pricing and liquidity conditions in the international financial system, but also problematic signaling effects (in the sense that their actions may have been interpreted by private market participants as reflecting troubling information known only to official sector agents). With surprisingly few surveyed reserve managers, particularly in EM, contacting the central bank of the reserve issuing country before reallocating assets during the crisis, these actions may have also been indicative of international co-ordination failures.

\section{LOOKING AHEAD-THE BALANCE OF VULNERABILITIES}

The preceding analysis raises questions over the prospects of a possible repeat dynamic in the next financial panic. Notwithstanding the inherent uncertainty associated with attempting to anticipate the reaction function of reserve managers (or any type of investor) in a period of international financial turmoil, the discussion below takes stock of the evolution of related vulnerabilities since the global financial crisis.

\section{Some Grounds for Cautious Optimism}

A number of developments point to reduced vulnerabilities going forward. First, uncollateralized deposit exposures with foreign commercial banks have reduced substantially as a share of reserve manager portfolios, from 15 percent in 2006 to now just 3 percent. Over the same period, deposits held at other central banks and the BIS have risen from 2 to 7 percent of reserve manager assets (Figure 8). This suggests reduced scope for reserve managers to again destabilize the short-term funding base of internationally active commercial banks.

Figure 8.

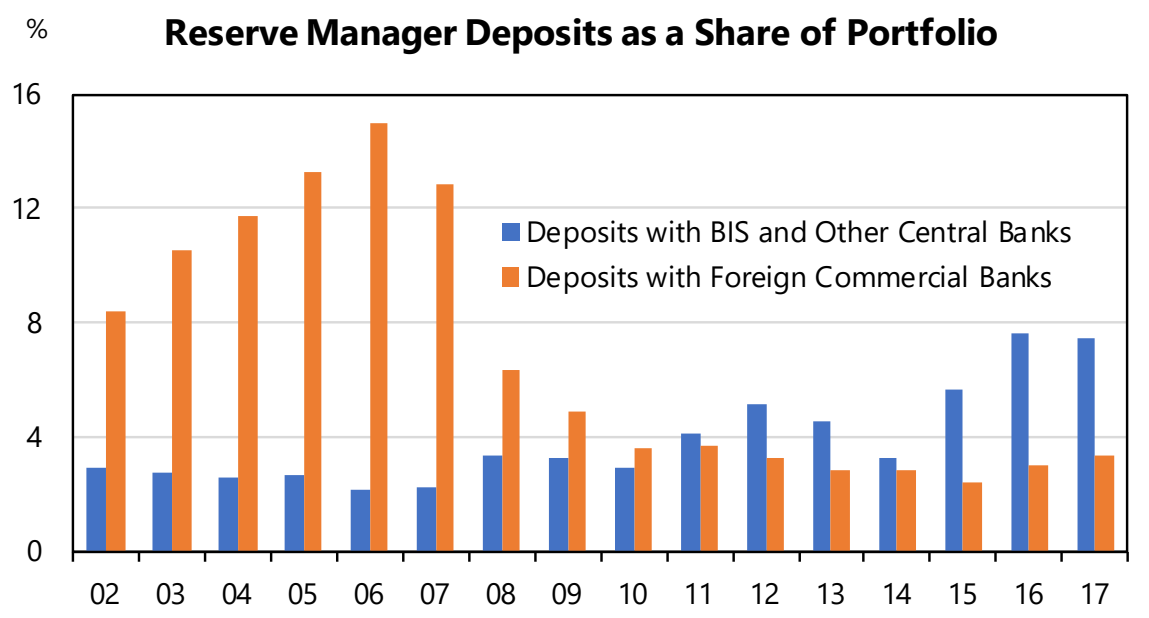

Source: IMF 
Second, events during the crisis have brought into sharper focus the need for reserve managers to better accommodate unexpected (often contingent) liquidity needs, prompting deeper analysis of the unstable relationship between credit and liquidity risk (and in particular, wider recognition that assets with low credit risk and price volatility may turn surprisingly illiquid in a crisis). To the extent this understanding has translated into more prudently calibrated liquidity buffers, there is reason to expect future shocks to global financial markets should elicit a less disruptive response from reserve managers.

Third, temporary bilateral foreign exchange swap lines, which in the crisis eased some of the problems experienced by central banks who had underestimated their foreign exchange liquidity needs, have in many cases now been converted into a broader and more permanent network comprising standing arrangements between six central banks in key financial centers. ${ }^{26}$ An array of open ended bilateral swap arrangements among other central banks has also been established. With a more extensive and coordinated safety net in place, unexpected foreign exchange liquidity demands should, at the margin, also be better accommodated.

Fourth, reserve managers, like many other asset owners after the crisis, are now more attuned to the risks associated with externally managed securities lending programs (and operational risk more broadly), thus dampening the prospect of another round of synchronized redemptions from shadow banking vehicles. This has been reflected in numerous ways, including greater focus on the reinvestment risk of cash collateral, more prescriptive investment eligibility requirements, more intrusive supervision and transparency to ensure compliance with these guidelines, and more rigorous counterparty controls.

And fifth, new accounting provisions associated with the transition from IAS39 to IFRS9, which will formally apply to around fifty central banks (with around half that number again also using it for guidance), could also help moderate procyclical portfolio adjustments by some reserve managers. Under the previous regime, loss provisioning required an actual trigger event and thus was backward looking, while under IFRS9, credit loss provisioning can be based on more stable, forward looking through-the-cycle estimates. Additionally, the abolition of the so-called 'tainting rule,' which required an entire hold-to-maturity portfolio to be marked-to-market in the event that just a single security from this tranche was sold before maturity, should also better enable reserve managers to carry procyclical risk exposures through the cycle.

\section{Remaining Vulnerabilities}

Nevertheless, a number of other considerations suggest a benign resolution is far from certain. First, the asset pool overseen by reserve managers is more concentrated and considerably larger than before the crisis, with the latter revealing itself in a high and/or rising ownership share of outstanding market capitalization. For instance, the share of global reserves overseen by a relatively small number of countries has again risen, with three

\footnotetext{
${ }^{26}$ This network comprises the Bank of Canada, the Bank of England, the Bank of Japan, the European Central Bank, the Federal Reserve, and the Swiss National Bank. These arrangements allow for the provision of liquidity in each jurisdiction in any of the five currencies foreign to that jurisdiction.
} 
countries managing nearly half, and ten nearly three-quarters (Figure 9). Furthermore, foreign exchange reserves have risen 55 percent, or \$4 trillion, since Q1-2009. (Put in context, this is a flow that exceeds the entire stock of assets managed by the relatively higher profile global hedge fund industry). As to the foreign official ownership share of various asset classes, it remains elevated in the case of U.S. sovereign debt (Figure 10), ${ }^{27}$ has risen noticeably in the case of non-traditional reserve issuing country debt (Figure 11), ${ }^{28}$ and is also rising in riskier asset classes (Figure 12). The allocation in foreign exchange reserves toward non-traditional and commodity sensitive (and thus procyclical) currencies - principally the Australian and Canadian dollars - has similarly risen, albeit from a low base (Figure 13). ${ }^{29}$

Figure 9.

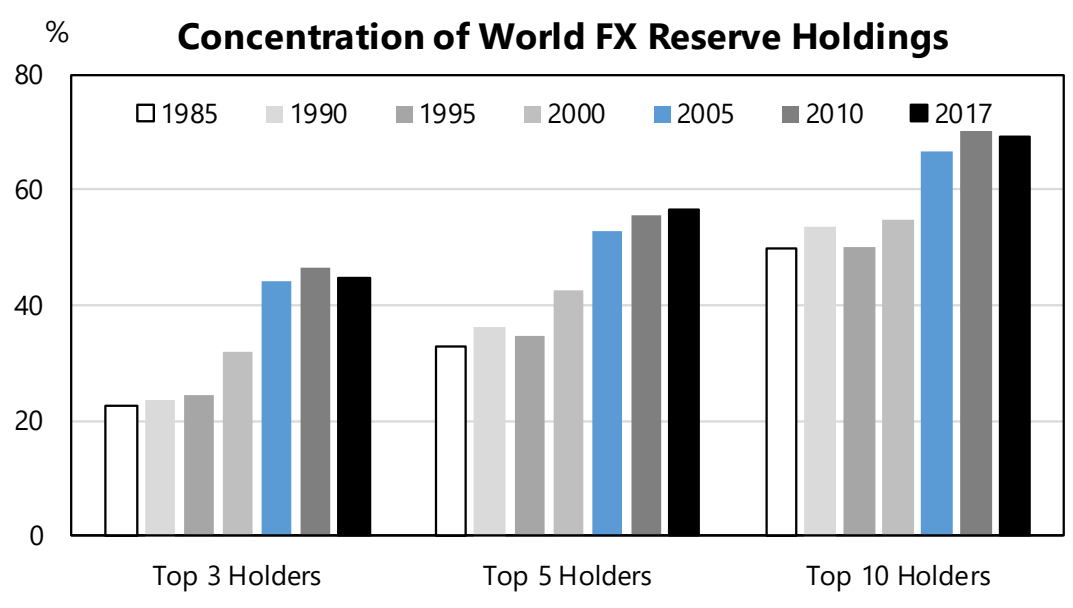

Source:IMF

\footnotetext{
${ }^{27}$ As TIC data compiled by the U.S. Treasury Department is based on the buyer's location and status at the point of purchase, not that of the ultimate beneficial owner, foreign official accounts purchasing U.S. assets through private sector intermediaries will be underrepresented.

${ }^{28}$ Traditionally, U.S. Treasuries have been widely viewed as enjoying monopoly-like status as a safe asset. These data, and recent research, suggest this picture may now be evolving. See for instance, Bordo and McCauley (2017).

${ }^{29}$ In a recent survey of 80 central banks accounting for half of world FX reserves, Carver and Glass (2017) report the following share of reserve managers which now have exposure to non-traditional reserve currencies: 55 percent in the Australian dollar, 47 percent in the Canadian dollar, 29 percent in Swedish krona, 27 percent in the Norwegian krone, 23 percent in the New Zealand dollar, 20 percent in the Danish krone, 15 percent in the Singapore dollar, and 12 percent in the Korean won. For a review of changes in the currency composition of foreign exchange reserves since World War II, see Eichengreen et al. (2016).
} 
Figure 10.

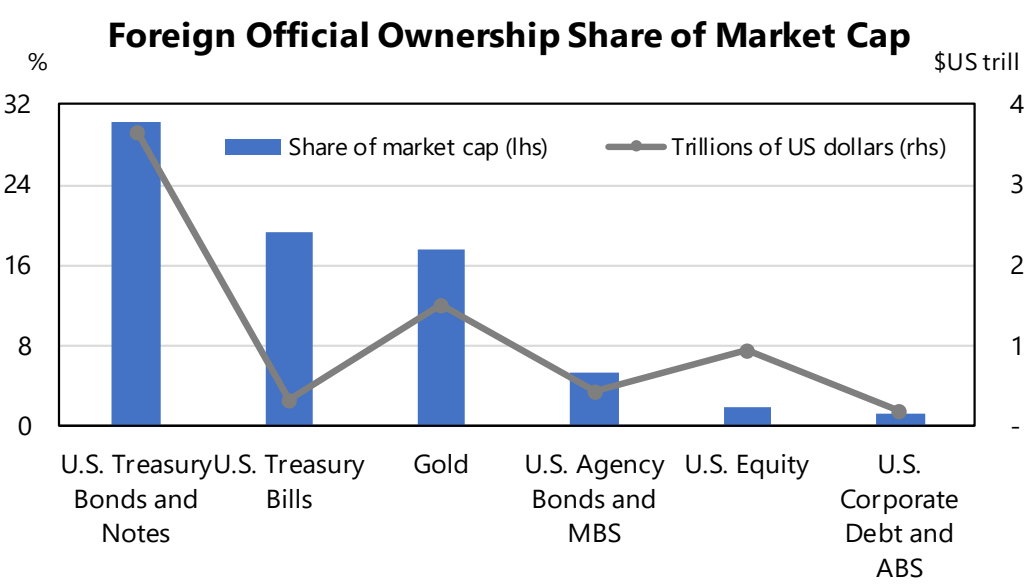

Source:U.S. Treasury Department, World Gold Council

Figure 11.

Foreign Official Ownership Share of Sovereign Debt:

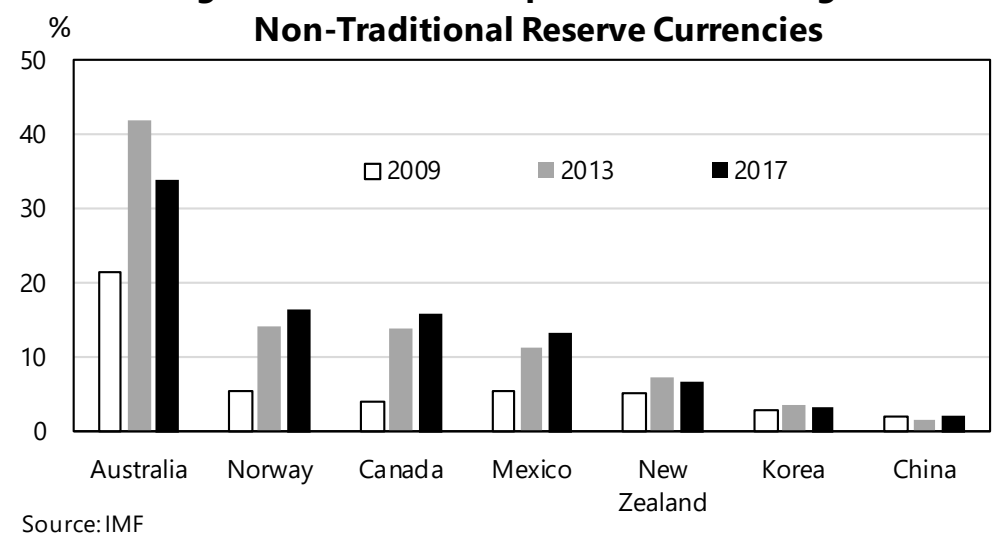

Figure 12.

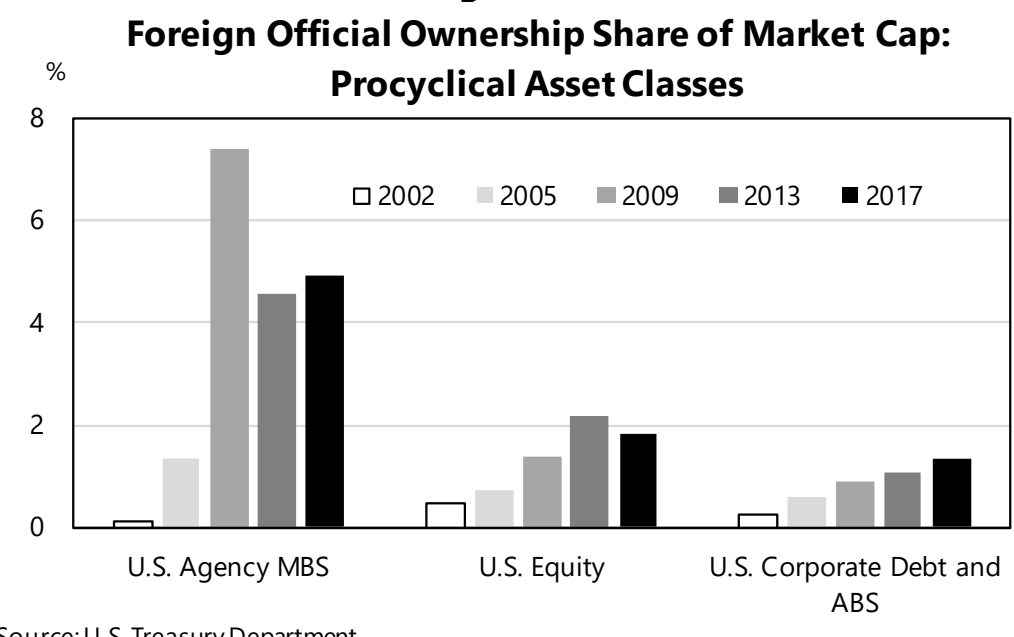

Source:U.S. Treasury Department 
Figure 13.

Share of World FX Reserves:

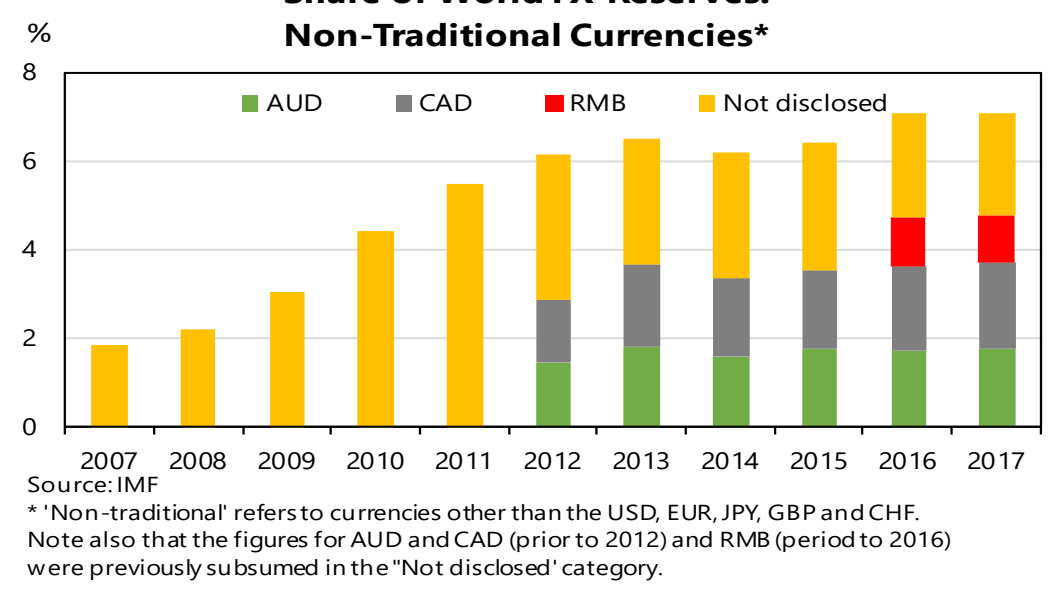

A second related consideration is that like many of their private sector counterparts, reserve managers have increasingly reached for yield as cash rates in the major industrialized countries have declined to historically low levels. This can be seen by way of the duration extension in spread product and Treasuries in the U.S. (Figure 14), the move into relatively high yielding non-traditional sovereign bond markets (recall Figures 11 and 13), and rising interest in asset classes beyond plain vanilla sovereign debt, including, but not limited to, equities (Figure 15). ${ }^{30}$ These moves broadly translate into increased exposure to procyclical risk factors like credit, volatility, and illiquidity risk. ${ }^{31}$

\footnotetext{
${ }^{30}$ It is also possible that the move beyond U.S. Treasuries into non-U.S. sovereign debt, quasi-sovereign and supranational debt reflects a more expansive assessment of what constitutes a 'safe asset.'

${ }^{31}$ A caveat is in order here - the concept of risk in a total portfolio context can differ from that when viewing (relatively volatile) asset classes on a standalone basis. The introduction of non-traditional asset classes in the portfolio mix may therefore be driven at least in part by a desire to hedge the risk factors associated with large, concentrated exposures to sovereign fixed income. For instance, reserve managers with exposure to listed equities often justify their inclusion on the basis of their purported inflation and interest rate hedging properties, without having to sacrifice liquidity. Diversification beyond core sovereign bond markets may become a more pressing issue as reserve currency issuing central banks begin unwinding unconventional monetary policy.
} 
Figure 14.

Foreign Official Duration Exposure in the U.S.

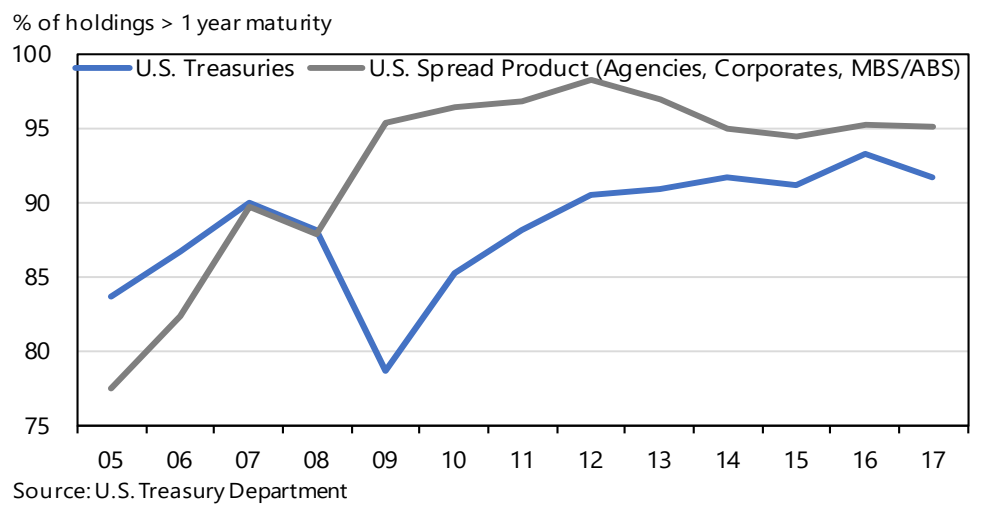

Figure 15.

Approved Asset Classes for Reserve Managers


Third, though the Financial Stability Board (FSB) and national banking regulators have urged a reduction in the mechanistic reliance on credit ratings, this appears to have gathered minimal traction among reserve managers. More than eighty percent indicated that the issuance of the FSB's Principles (later endorsed by the G20) aimed at reducing the mechanistic reliance on credit ratings have not resulted in a change to their investment policies, while three quarters of reserve managers reported not having reduced their reliance on ratings in a broader sense (Carver, 2013). Moreover, just under half of surveyed reserve managers continue to automatically divest exposure when minimum credit thresholds are breached, typically a double-A or single-A rating (Morahan and Mulder, 2013). With credit risk having recently returned to reserve manager portfolios, the prospect of procyclical firesales induced by rating downgrades should not be entirely ruled out.

Fourth, it is uncertain as to whether the proliferation of foreign exchange swap line arrangements since the crisis will prove to be effective, with the associated risk that some 
institutions underprovision for emergency liquidity needs. ${ }^{32}$ The operational effectiveness of swap lines as safety nets can only be gauged with confidence in a crisis-type environment, due in part to uncertainties over conditionality provisions and political economy constraints. ${ }^{33}$ Among others, the Chiang Mai initiative, which since inception in 2000 has no record of activation, offers food for thought in this respect. It should also be cautioned that many of the swap arrangements established by China in recent years were done so primarily to facilitate trade flows, not to address liquidity shortfalls experienced by trade partners in a crisis. More broadly, dysfunction in foreign exchange swap markets has extended from the crisis up to the present time (as reflected in a persistently wide cross currency basis), but with key central banks displaying less appetite for intervening through swap lines to restore equilibrium conditions (Allen et al., 2017).

Finally, flow patterns in the three mini-shocks since the global financial crisis-over euro area breakup concerns in 2011, the 'taper tantrum' of 2013, and the RMB 'devaluation' of 2015 - open the possibility that reserve manager procyclicality has been moderated somewhat but not eliminated (Figure 16). In the 2011 and 2015 episodes, ${ }^{34}$ reserve managers again sold risk assets, withdrew deposits from foreign commercial banks and increased deposits with the BIS - just as in the global financial crisis (albeit on a reduced scale). In the taper tantrum, which had a different dimension in that growth expectations and advanced economy risk assets were resilient while short and long-term risk free interest rates backed up, reserve managers also moved in the direction of the wider market. But in general, the flows in these episodes were smaller than in the crisis, making it difficult to draw firm conclusions. An optimistic interpretation would be that the reduced magnitude of procyclical flows indicates better preparedness by reserve managers. A less benign inference is that these actions simply accord with the reduced severity of the post-2008 economic disturbances, leaving open the possibility that a larger shock could still elicit a wave of destabilizing flows by reserve managers.

\footnotetext{
${ }^{32}$ Underprovisioning could also be a potential concern where the sharp increase in foreign currency borrowing by EM corporates since the crisis raises sudden stop risk for large firms that do not have formal (ex-ante) access to central bank liquidity facilities, but may be granted it in extremis.

${ }^{33}$ As a form of foreign debt, it should be noted that foreign exchange swaps cannot replace fundamental balance of payments adjustment, and that their treatment in the case of restructuring and Fund-supported programs has yet to be determined.

${ }^{34}$ While it is technically possible that the large official sector sales of U.S. Treasuries during the 2015 RMB devaluation scare (in excess of $\$ 200 \mathrm{bn}$ ) reflected official selling from China as the authorities sought to stabilize the RMB, TIC data point to a decline in (combined official and private) Chinese holdings of Treasuries of just $\$ 32$ bn during the period.
} 
Figure 16.

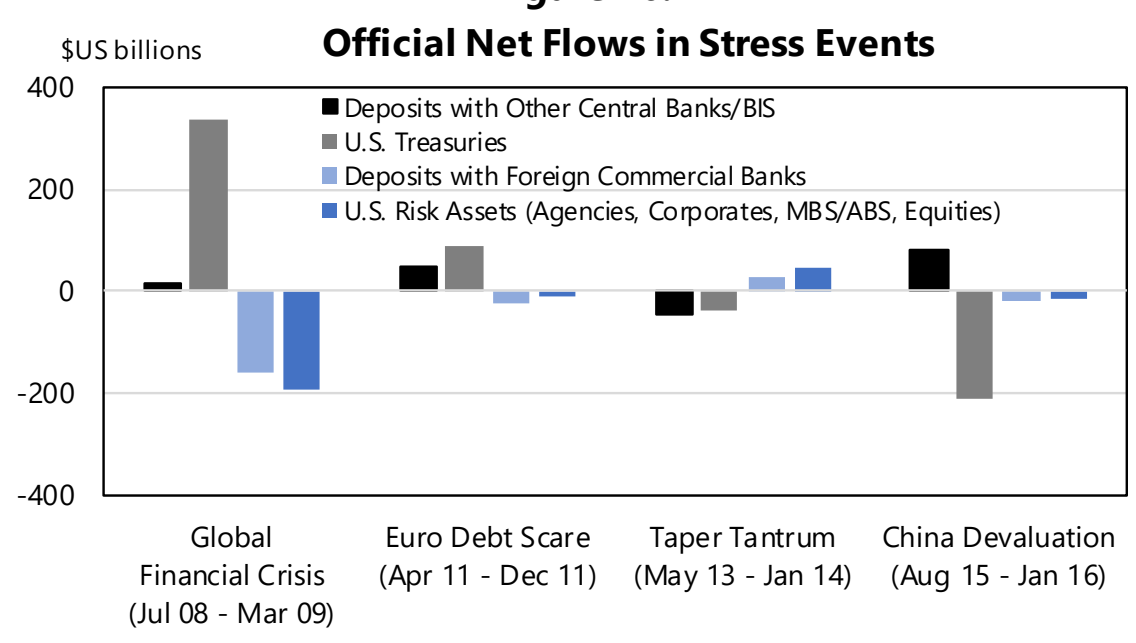

Source:IMF, U.S. Treasury Department

\section{Dampening Procyclicality-What Can Be Done?}

Beyond weighing potential vulnerabilities, further questions remain as to what, if anything, can practically be done to ensure reserve management is less procyclical in the future. One obvious (corner) solution is that credit and liquidity risk be purged from reserve portfolios altogether, to be managed exclusively in savings-based SWFs with a single objective function (return generation). But where such an arrangement might not be practical, raises a new set of intractable institutional design issues, or might not result in any material difference in procyclical investment impulses, ${ }^{35}$ there may be simpler alternative means of limiting the scope for negative system-wide externalities to again result from the inadvertently synchronized behavior of reserve managers. ${ }^{36}$ But just as prevention is preferable to cure, bolstering resilience means taking remedial steps ahead of trouble. If not adequately prepared, reserve managers will again be left only with suboptimal choices in a crisis, likely exacerbating the tension between domestic and international financial stability. ${ }^{37}$

\footnotetext{
${ }^{35}$ While the deployment of 'surplus reserves' in intergenerational savings-based SWFs might help to relieve central banks from some of the earlier discussed stability tensions - SWFs typically have a single objective and thus more degrees of freedom in portfolio management - if the latter do not enjoy the appropriate governance and institutional design features, procyclicality among sovereign institutions may simply continue albeit under a different owner. Appropriate (long-term oriented) incentive design is critical in this respect (see Jones, 2016). Norway was the most prominent example of a SWF whose governance structure allowed it to maintain a countercyclical orientation through the depths of the crisis.

${ }^{36}$ Of course, procyclicality in financial markets cannot be leveled at reserve managers alone. Equivalently, there are limits as to what reserve managers alone can do to dampen procyclicality.

${ }^{37}$ While reserve managers should not be expected to sacrifice their domestic financial stability obligations at the altar of international financial stability preservation, the measures in Section $\mathrm{V}$ are more modestly aimed at ensuring their domestic responsibilities can be fulfilled without destabilizing the wider financial system.
} 


\section{Governance and Communication Challenges}

Holding procyclical exposures through-the-cycle requires a governance structure that can accommodate inevitable periods of discomfort occasioned by volatility. This is especially pertinent where the growth in reserves has increased the sensitivity of the profits and capital position of the central bank to fluctuations in the value of the reserve portfolio. ${ }^{38}$ For reputational reasons, central banks can also be highly sensitive to credit risk incurred in reserve portfolios, well beyond the pure financial loss (and threat to capital) that may result from it. The asymmetry by which reserve managers are praised quietly when generating profits, but criticized loudly when incurring losses, can entrench incentives to run with the herd in times of stress. ${ }^{39}$ Two elements (one internally-focused, the other externally-oriented) can assist in addressing these sensitivities.

First, an increased focus on return-generation should be accompanied by more formal engagement of the executive. Where strategic decisions about the reserve portfolio (including the definition of the investable universe, target allocations, delegation and counterparty guidelines, etc. $)^{40}$ are framed in the broader context of what is deemed an acceptable riskreturn trade-off for the institution as a whole, reserve managers should have greater confidence that their actions have institutional-wide support (including where these actions might generate valuation losses on occasion). ${ }^{41}$

Second, and notwithstanding the highly-country specific nature of external governance arrangements, ${ }^{42}$ a policy of preemptive external stakeholder engagement on the rationale for

\footnotetext{
${ }^{38}$ In the case where reserves exceed insurance needs and the domestic currency is used for determining reported losses for accounting purposes, it is a natural candidate as numeraire for institutions that are highly sensitive to valuation losses. A number of central banks have publicly rationalized adjustments to their portfolio allocations with the desire to limit the variability of the value of the portfolio measured in domestic currency. See McCauley (2008), Borio et al. (2008b) and IMF (2013) for related discussion on the choice of numeraire.

39 These sensitivities can derive from asymmetric income distribution rules where central bank profits (owing, at least in part, from valuation changes in the reserve portfolio) are routinely paid out to the government, while losses are not replenished through automatic recapitalization.

${ }^{40}$ Given the tight link between operational risk and reputational risk, most central banks include reputational risk as a part of the responsibilities associated with operational risk activities. An in-depth discussion of operational risk is beyond the scope of the paper.

${ }^{41}$ Particularly where in-house expertise is lacking, some institutions have investments in risky asset classes outsourced to third party managers in an effort to shield themselves from reputational risk which can surface when losses are reported. This might also be done to avoid perceptions that the central bank is utilizing inside information for its own pecuniary benefit. Delegating authority to external managers is not, however, without its own governance challenges, including principal-agent frictions and loss of oversight capacity.

${ }^{42}$ In the area of reserve management, there are no internationally binding disclosure practices - these are left to the discretion of national authorities, reflecting a mixture of economic, institutional and political factors. The IMF's Special Data Dissemination Standard (SDDS), Guidelines on Foreign Exchange Reserve Management,
} 
accepting certain types of risks - and thus the volatility and (mostly unrealized) losses the institution can expect to experience over a cycle — can mitigate costly knee-jerk reactions (and in extremis, threats to political independence) during difficult times. After communicating the rationale for risk acceptance, central banks with relatively high levels of credibility and independence are likely to encounter less external pressure to respond procyclically to losses. Though rarely straightforward to determine in practice, disclosure practices must aim at optimizing the tradeoff between the legitimacy-enhancing effects of providing additional information to various stakeholders on the one hand, and on the other, the pressure to divest (rationally held) exposures in times of stress. ${ }^{43}$

\section{Tranching}

The crisis was a visceral reminder of the costliness of underestimating liquidity needs. It is notable that more central banks reported problems with the liquidity of their reserves than the level per-se (see Morahan and Mulder, 2013). ${ }^{44}$ The tranching of reserves into distinct liability-immunizing and riskier investment portfolios requires careful calibration - too few resources in the former will result in the less liquid, procyclical risk exposures in the latter having to be sold at the worst time to make up the shortfall..$^{45}$ And it is easier said than done, reflecting the inherent uncertainties in estimating tail risk and binary (regime switching) variables like market liquidity which standard risk management techniques struggle to accommodate. But just as refining estimates of reserve adequacy (i.e., the appropriate level of reserves) has attracted renewed attention since the crisis (see IMF, 2015, 2016), so too there is need for reserve managers to strengthen their analysis of time-varying microstructure conditions in the asset classes and instruments in which they invest. While stepped up market

and Code of Good Practices on Transparency in Monetary and Financial Policies (MFP Transparency Code) come closest. See also, Truman and Wong (2006).

${ }^{43}$ Countries that rank high in disclosures concerning reserve management practices tend to rank high in disclosure standards in other areas, including other central bank, public sector and financial functions (notably common law countries; La Porta et al. 1998). See IMF (2013) and Truman and Wong (2006) for treatments focused on reserve management. It should be noted however that the broad trend towards greater central bank independence has increased the emphasis on accountability and transparency, encouraging a strengthening of both internal and external governance (including through greater disclosure).

44 The experience of some central banks has shown that the pledging of reserves as collateral with foreign financial institutions as support for loans to either domestic entities or foreign subsidiaries of the reserve management entity can render reserves illiquid until loans have been repaid. Liquidity risks have also arisen from the direct lending of reserves to such institutions when shocks to the domestic economy led to the borrowers' inability to repay their liabilities.

${ }^{45}$ It is not uncommon for the liquidity tranche to be split into a transaction tranche and a liquidity tranche, where the transaction tranche reflects the needs for day-to-day transactions. Such transactions are frequent in some countries where the central bank plays a significant role in setting the exchange rate through intervention, or when government debt in foreign currency requires frequent foreign currency outlays. In some countries, tranching is also used to immunize market and foreign exchange risks on the reserve balance sheet, by establishing characteristics for a particular asset portfolio that match those of a group of counterpart foreign liabilities. 
surveillance activities can assist in this regard, they cannot substitute for more formal portfolio stress testing techniques.

\section{Procyclical Risk Management and Rebalancing}

The crisis revealed considerable mechanical reliance on inputs that tightly covary with the economic cycle — credit ratings, CDS spreads and price volatility — in driving the risk management and portfolio rebalancing actions of reserve managers. While these data can serve as useful inputs for the market surveillance activities of central banks, their application in a reserve management context requires careful consideration. Mechanistic reliance on credit ratings can lead to forced selling in stressed market conditions (thus making the stabilization task of other central banks more difficult) and unintentionally increase concentration risk in the remainder of the portfolio. Alternative approaches include the following: combining procyclical indicators like credit ratings and CDS spreads with various other (slower moving) fundamental inputs in the risk management and benchmarking process; using threshold breaches to trigger risk reviews rather than involuntary selling; and spreading asset sales across a rating corridor rather than concentrating sales at a single (binary) threshold. ${ }^{46}$

\section{Customized Benchmarks}

Capitalization-weighted benchmarks have procyclicality built into them, with an additional pernicious feature in fixed income markets in that the most heavily indebted issuers attract the most capital. Traditionally, these drawbacks were partly offset by greater liquidity, but even this benefit has diminished in light of changes to market structure since the crisis. To the extent that investment guidelines allow portfolios to deviate from cap-weights, a key question arises as to whether this should find expression in the discretionary tactical decisions of the manager (subject to constraints), or instead customized benchmarks calibrated to the unique liability profile and preferences of the central bank. While active trading can help inform the central bank's market surveillance activities, the empirical record on active management is mostly unpersuasive, and reserve managers, like all investors, are vulnerable to procyclical behavioral biases in stressed market conditions. By contrast, customized benchmarks are transparent, scalable, and immune to the vagaries of emotions, thus capable of yielding a more consistent alignment between institutional expectations and realized outcomes.

\footnotetext{
46 The relevant passage in the IMF's Revised Guidelines for FX Reserve Management reads as follows: “The management of credit risk should aim at not relying solely and automatically on the assessment of credit rating agencies. Reserve managers that have the capacity need to internally analyze and understand the amount of credit risk to which they may be exposed as a result of reserve management activities, in order to avoid overreliance on credit rating agencies. Accordingly, they may put in place internal credit risk assessment systems for assessing and monitoring their counterparties - both sovereign and non-sovereign." Note that half of the managers surveyed in Carver (2013) report having increased resources in recent years to develop internal credit assessment capabilities.
} 


\section{Duration Targets}

When duration targets are more often set on the basis of fixed return objectives than liability hedging considerations, as reported in the survey results of Morahan and Mulder (2013), this can perversely lead to maximum risk taking when spreads are tightest and policy rates lowest. Where possible, the structure of liabilities should feature as the key determinant of duration exposure, ${ }^{47}$ most notably in hedging portfolios, with return targets for (riskier) investment portfolios periodically reset in the context of prevailing risk-free yields to reduce the pressure on reserve managers to reach for yield - action that might expose the institution to risks it is ill-suited to bear.

\section{Countercyclicality}

Finally, though the conservative orientation of many reserve managers constrains their ability to lean against trends in risk assets, the public policy case for leaning into persistent flow imbalances in reserve currencies may well be stronger. For instance, a wide cross currency basis emanating from imbalanced market conditions (i.e. one-way flows) ${ }^{48}$ - such as that seen most notably in the Japanese yen in recent years owing to domestic institutional hedging of foreign assets - can see hedging costs become so prohibitive they prompt investors and corporations to run unhedged currency risk, even if they are not well equipped to deal with the possible consequences. By leaning into a widening basis, reserve managers stand to both harvest additional yield in reserve currencies, and play a constructive role in rebalancing the market, thus encouraging the prudent hedging of cross-border capital flows. ${ }^{49}$

\section{Conclusion}

Leaning against the wind in support of domestic stability objectives-i.e., countercyclical monetary policy, emergency lending during banking panics, and foreign exchange intervention when market conditions turn disorderly — has long characterized the overarching

\footnotetext{
${ }^{47}$ In this context, the concept of liabilities relates more to the precautionary purposes for holding reserves, i.e. the policy objectives they serve and the conditions under which they may be drawn. This is a somewhat different concept from the direct funding cost of reserves, captured by 'tangible' on-balance sheet liabilities typically comprised of currency in circulation and commercial bank reserves - both of which are difficult to pin down from a duration/interest rate sensitivity perspective (currency in circulation is a perpetuity with no interest rate, and reserves may or may not be remunerated at the policy rate). Admittedly, basing duration hedging benchmarks on 'virtual' (or contingent) liabilities as distinct from tangible liabilities could create communication challenges with respect to the accounting treatment of changes in asset and liability valuations.

${ }^{48}$ The cross currency basis represents the difference between the cost of borrowing currency A directly in the cash market, and the interest paid to borrow currency A by borrowing currency B and swapping it for A. In other words, it measures the cost differential between borrowing in the currency swap market and the physical money or bond market. If covered interest parity (CIP) holds, the basis should be zero. Prior to the global financial crisis, only negligible deviations from CIP were documented, even during periods of high volatility, but significant deviations have since become commonplace as commercial dealers and other private sector agents have retreated from the foreign exchange market. See Section V for further discussion.
}

${ }^{49}$ Around one quarter of surveyed reserve managers have done just this since 2016 (Carver and Glass, 2017). 
response function of central banks. Yet in possibly seeking to correct earlier misjudgments of liquidity and/or investment risk during the global financial crisis, this paper documents how the procyclical actions of reserve managers inadvertently likely made the stabilization efforts of reserve-currency issuing central banks more difficult (even if at the margin). Furthermore, while there are some grounds for cautious optimism, a broad assessment of related

vulnerabilities since the crisis suggests a more benign outcome in the next period of financial turbulence cannot be assured.

As reserve management continues to evolve in the direction of increased size, risk taking and complexity to mirror the practices of private investors, so too related policy advice needs to keep pace. This owes particularly to the formidable difficulties associated with provisioning for crisis-like environments, and the fact that, despite the rapid growth in reserves, most central banks generally do not have an established track record of managing portfolios with considerable investment and illiquidity risk - and the associated governance challenges this entails. Further guidance on 'constrained discretion' principles for reserve management (reflecting both the multi-functional nature of central banks, and wide differences across them), coupled with analysis of the conditions under which the synchronized investment practices of reserve managers might reinforce the actions of other private institutions, therefore seem worthy avenues for future research. In the meantime, the task of ensuring reserve managers take measures in good times that will allow for smoother navigation through periods of turmoil likely presents an ongoing policy challenge. 


\section{REFERENCES}

Aliber, Robert Z., 2011, "Financial Turbulence and International Investment," BIS Papers No 58, in 'Portfolio and Risk Management for Central Banks and Sovereign Wealth Funds,' Proceedings of a Joint Conference Organised by the BIS, ECB and World Bank, Basel.

Allen, William, Gabriele Galati, Richhild Moessner, and William Nelson, 2017, "Central Bank Swap Lines and CIP Deviations,” De Nederlandsche Bank Working Paper No. 566, Amsterdam.

Baba, Naohiko, Robert N. McCauley, and Srichander Ramaswamy, 2009, "US Dollar Money Market Funds and Non-US Banks,” BIS Quarterly Review, March, Basel.

Bank of England, 2014, "Procyclicality and Structural Trends in Investment Allocation by Insurance Companies and Pension Funds," Discussion Paper, London.

Bernadell, Carlos, Pierre Cardon, Joachim Coche, Francis X. Diebold, and Simone Manganelli, 2004, "Risk Management for Central Bank Foreign Reserves," European Central Bank, Frankfurt.

Bordo, Michael, and Robert N. McCauley, 2017, "A Global Shortage of Safe Assets: A New Triffin Dilemma?” Atlantic Economic Journal, Vol 45, No 4: 443-451.

Borio, Claudio, Jannecke Ebbesen, Gabriele Galati, and Alexandra Heath, 2008a,: "FX Reserve Management: Elements of a Framework," BIS Papers No 38, Basel.

Borio, Claudio, Gabriele Galati and Alexandra Heath, 2008b, "FX Reserve Management: Trends and Challenges," BIS Papers No 40, Basel.

Carver, Nick, 2013, “RBS Reserve Management Trends, 2013,” Central Banking Publications, London.

Carver, Nick, and Emma Glass, 2017, “HSBC Reserve Management Trends, 2017,” Central Banking Publications, London.

Dooley, Michael P., David Folkerts-Landau, and Peter M. Garber, 2003, "An Essay on the Revived Bretton Woods System,” NBER Working Paper No 997, Cambridge.

,2008, “Asia, Interest Rates, and the Dollar,” Deutsche Bank Global Markets

Research, London.

, 2014, “The Revived Bretton Woods System's First Decade,” NBER Working Paper No. 20454, Cambridge.

Eichengreen, Barry and Marc Flandreau, 2016, "A Century and a Half of Central Banks, International Reserves and International Currencies," in Michael D. Bordo, Oyvind Eitrheim, 
Marc Flandreau and Jan F. Qvigstad (eds), 'Central Banks at a Crossroads: What Can We Learn from History?' Cambridge University Press, Cambridge.

Eichengreen, Barry, Livia Chitu, and Arnaud Mehl, 2016, "Stability or Upheaval? The Currency Composition of International Reserves in the Long Run," IMF Economic Review, Vol 64, No 2, Washington D.C.

Financial Stability Board, 2017, "Policy Recommendations to Address Structural Vulnerabilities from Asset Management Activities," Basel.

Fleming, Michael J., and Nicholas J. Klagge, 2010, “The Federal Reserve's Foreign Exchange Swap Lines," Vol 16, No 4, Federal Reserve Bank of New York, New York.

Hong Kong Monetary Authority, 1997, "Styles of Risk Management in Central Bank Reserves Management," Quarterly Bulletin, Hong Kong.

International Monetary Fund (IMF), 2013, “Guidelines for Foreign Exchange Reserve Management," International Monetary Fund, Washington D.C.

, 2014, "How Do Changes In The Investor Base And Financial Deepening Affect Emerging Market Economies?” Global Financial Stability Report, Chapter 2, April, International Monetary Fund, Washington D.C.

,2015, “Assessing Reserve Adequacy_Specific Proposals,' International Monetary Fund, Washington D.C.

,2016, "Guidance Note on the Assessment of Reserve Adequacy and Related Considerations," International Monetary Fund, Washington D.C.

Jones, Bradley A., 2016, "Institutionalizing Countercyclical Investment: A Framework for Long-term Asset Owners,” IMF Working Paper 16/38, Washington DC.

,2017, "Leaning With the Wind: Long-term Asset Owners and Procyclical Investing," Journal of Investment Management, Vol 15, No 2: 16-38.

La Porta, Rafeal, Florencio Lopez-de-Silanes, Andrei Schleifer and Robert W. Vishny, 1998, "Law and Finance," Journal of Political Economy, Vol 106, No 6: 1113-55.

McCauley, Robert N., 2008, "Choosing the Currency Numeraire in Managing Official Foreign Exchange Reserves", in Pringle, Robert, and Nick Carver (eds), 'RBS Reserve Management Trends 2008,' Central Banking Publications, London.

McCauley, Robert N., and Jean-François Rigaudy, 2011, "Managing Foreign Exchange Reserves in the Crisis and After," BIS Papers No 58, in 'Portfolio and Risk Management for Central Banks and Sovereign Wealth Funds,' Proceedings of a Joint Conference Organised by the BIS, ECB and World Bank, Bank for International Settlements, Basel. 
McGuire, Patrick, and Goetz von Peter, 2009, "The US Dollar Shortage in Global Banking and the International Policy Response,” BIS Working Paper No 291, Basel.

Morahan, Aideen, and Christian Mulder, 2013, "Survey of Reserve Managers: Lessons from the Crisis," Working Paper 13/99, International Monetary Fund, Washington D.C.

Nugée, John, 2015, "Current Issues in Central Bank Reserves Management," Proceedings of the Oesterreichische Nationalbank Conference on Asset-Liability Management, Vienna.

Obstfeld, Maurice, Jay C. Shambaugh, and Alan M. Taylor, 2009, "Financial Instability, Reserves, and Central Bank Swap Lines in the Panic of 2008," American Economic Review, Vol 99, No 2: 480-86.

Organization for Economic Cooperation and Development (OECD), 2014, "Institutional Investors and Long-term Investment," Project Report, Paris.

Pihlman, Jukka, and H van der Hoorn, 2010, "Procyclicality in Central Bank Reserve Management: Evidence from the Crisis," Working Paper 10/150, Washington D.C.

Pringle, Robert, and Nick Carver, 2008, "RBS Reserve Management Trends, 2008," Central Banking Publications, London.

London.

, 2009, “RBS Reserve Management Trends, 2009,” Central Banking Publications,

Rodrik, Dani, 2006, "The Social Cost of Foreign Exchange Reserves," International Economic Journal, Vol 20, No 3: 253-266.

Truman, Edwin M. and Anna Wong, 2006, "The Case for an International Reserve Diversification Standard," Working Paper 06-2, Institute for International Economics, Washington D.C. 